\title{
THE STABILITY OF THE GEODETIC POINTS IN CONNECTION WITH GEODYNAMIC PROCESSES IN AZERBAIJAN
}

\author{
Magsad GOJAMANOV \\ Department of Geodesy and Cartography, Baku State University, 23, Z. Khalilov str., AZ1148, Baku, Azerbaijan Republic, \\ Tel.:+99412538 0170, Fax:+994125983376 \\ Corresponding author's e-mail: mgodja@yandex.ru
}

\begin{tabular}{l} 
ARTICLE INFO \\
\hline Article history: \\
Received 14 January 2014 \\
Accepted 1 July 2014 \\
Available online 16 July \\
\hline Keywords: \\
Geodetic networks \\
Geological structure \\
Leveling \\
Geodynamics \\
Absheron Peninsula \\
Seismic activity \\
Landslide processes \\
Geodynamic polygons
\end{tabular}

\section{ABSTRACT}

This article provides information about the geological structure of the territory of Azerbaijan Republic, the results of the analysis of tectonic movements, analysis of the plan geodetic networks, assessment of deformations in geodetic networks, interpretation of the results of repeated leveling works on the Absheron Peninsula, about the mud volcanoes and seismic situation and also describes the geodynamic polygons created in order to study the recent movements of the Earth's crust on the territory of the Azerbaijan Republic. These polygons were experimental in the territory of the former Soviet Union.

\section{INTRODUCTION}

Modern development of geodesy fundamentally changed the requirements to geodetic provision. Transition of the geodetic provision on the satellite methods involves the creation of the initial vertical base and its characteristics would be consistent with the capabilities of modern technology of operational satellite definitions (Makarenko, 1996). This requires increased accuracy of planned basis while dramatically reducing requirements to the density, but a more favorable attitude of the points provisioning networks.

The State Geodetic Networks, if it is not systematically updated and do not improve, gradually aging, loses part of points, loses accuracy in its individual parts, especially due to the recent movements of the Earth's crust. Main centers of recent movements of the Earth's crust on the territory of the Azerbaijan Republic (AR) are the phenomena of the tectonic character, high seismic activity, caused by technogenic and anthropogenic processes. In order to study the geodynamic regime in the most seismically active zones AR were created six geodynamic polygons (GDP): Absheron special network -80, Shamakhi GDP, Caspian GDP, Sheki-Kurdamir GDP, Technogenic polygon Absheron, GDP Azerbaijan NPP. In this regard it has to review briefly the tectonic position of Azerbaijan.

\section{TECTONIC POSITION OF AZERBAIJAN}

Tectonic position of Azerbaijan in the general structure of the Caucasus and adjacent folded regions is determined by the main structural complexes: anticlinoria of the Greater and Lesser Caucasus (East End) and separating them Kur River between mountain deflection (Khain, 2005; Museibov, 1998). These patterns go under the latest deposits meridional depression of the Caspian Sea. The Caspian Sea is located at the junction of large, heterogeneous geostructural elements of the Northern Caspian, the Caucasus, Central Asia (Kazakhstan, Turkmenistan) and Northern Iran. Caspian depression consists of two basins: the Mid-Caspian and South Caspian separated by the Absheron - Balaxany young vertical movements.

Analysis of the geological structure of Azerbaijan shows that now observed deep faults have a considerable length and extending mainly from North-West to South-East and North-East to SouthWest divide the whole territory of the Republic (Fig. 1). In the Lesser Caucasus recent movements are differentiated and, if in extreme mountain zones occur uplift with a speed of 4-5 $\mathrm{mm} /$ year, in the inland areas, on the contrary, lowering of $0.1-1 \mathrm{~mm} / \mathrm{year}$. Kura-Araz lowland in general is sinking and its speed reaches 0.5-5 mm/year and in Mil-Karabakh an inclined plain overall speed is $2-3 \mathrm{~mm} /$ year. In Adjinour zone differential uplift with a speed of 4$6 \mathrm{~mm} /$ year. Ganykh-Agrichay zone, located between Adjinour and the Greater Caucasus is also an area of uplift (4 mm/year).

It is known that the information about the parameters of the dynamics of geodynamic processes in general is received by the geodetic methods. In turn the geodynamic processes affect to the geodetic 


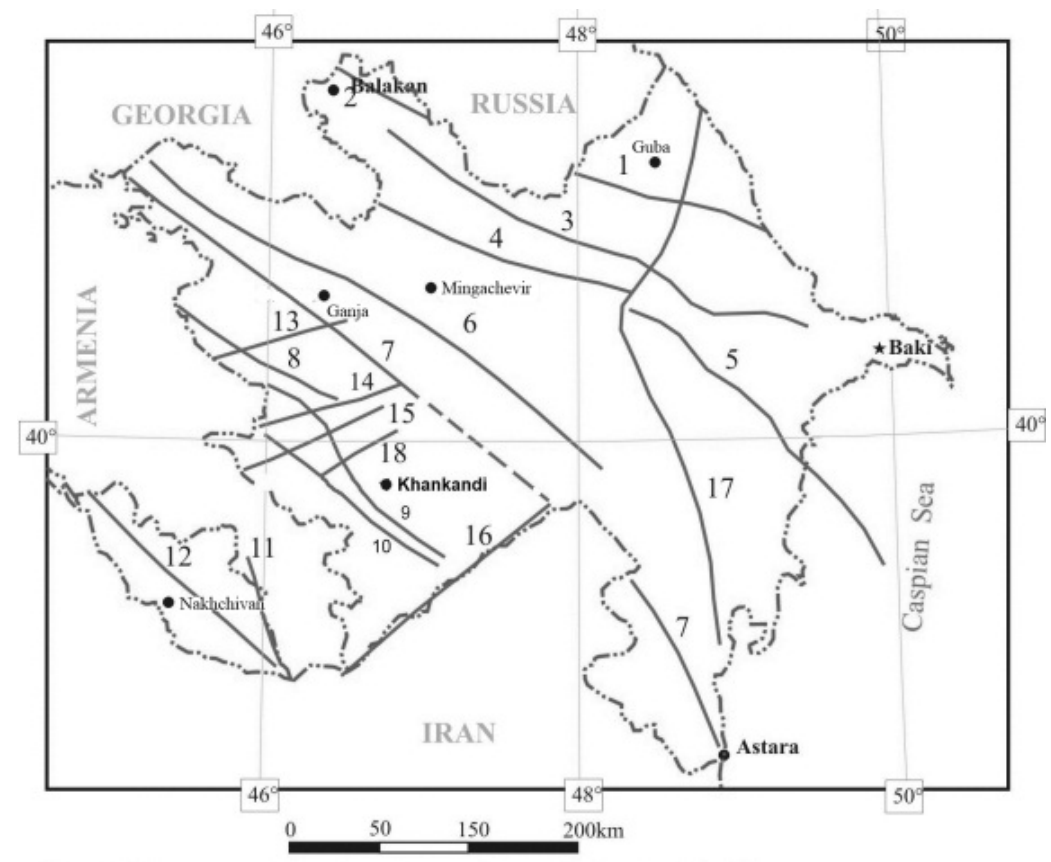

Fig. 1 Diagram of the locations of deep faults in AR (Khain, 2005).

1-Siyazan; 2-Maincaucasus; 3-Kaynar-Zangy; 4-North-Ajinohur; 5-AjiAlyat; 6-Kur; 7- Small Caucasus; 8-Murovdag; 9-Karabakh; 10Bashlibel;11-Hankavan-Syunik;12-Nakhchivan;13-Xandar-Xachbulag; 14-Murovdag-Zod;15-Tartar;16-Lower-Araz.

networks and deform them. In this regard the next chapter presents the results of the analysis of accuracy and evaluation of deformation values in the State Plan Geodetic Network of the Republic of Azerbaijan received by us in our researches (Gojamanov, 2004).

\section{ANALYSIS OF THE PLAN GEODETIC NETWORKS AND ASSESSMENT OF THEIR DEFORMATIONS}

State Geodetic Network (SGN) of Azerbaijan has never been independent and it was part of the general system of the SGN of the former USSR (Kashin, 1999). History of regular surveying on the territory of the South-Eastern Caucasus, including Azerbaijan, dates back to 1847 . During 1847-1853 the triangulation 1 class of a rather high quality was laid from Poti on the Black Sea to Sumgait on the Caspian. Some points of the Transcaucasia triangulation preserved in Azerbaijan to date.

Until 1953 the whole territory of the AR was covered with a network triangulation I, II, III and IV classes on basic provisions of 1939. Triangulation of the 1 class - media coordinate system 1942 - was built in years 1929-1930. In 1968-1972 Tbilisi Enterprise No 4 of Main Administration of Geodesy and Cartography (QUQK) was performed the reconstructtion of the SGN AR and in 1979-1985 the Baku Enterprise No 16 QUQK was repeatedly reconstructted, concentration and repair of networks 2, 3 and 4 classes on «Basic provisions of the 1961». In other words, the SGN of AR has been built for a number of years by various agencies according to the different documents (Gojamanov, 1998) without benefit of adjustment, which led to a heterogeneous network and decrease of its quality.

Now in Azerbaijan there are two implementations of reference frame system of coordinates (SC) associated with Krasovsky ellipsoid: $\mathrm{SC}-42$ and SC-95 (Efimov, 1995). As is known, SC-42 was resulted from the adjustment 87 polygons, among which the Caucasian region (Armavir - Tbilisi - Baku - Batumi). In 1995, the results of a joint adjustment astronomic-geodetic (AGN), space (cosmic) (CGN) and Doppler (DGN) networks established SC-95 (Bazlov and others, 1996). The existence of two systems of coordinates (SC-42 and SC-95) on the territory of the Republic gave the opportunity to conduct a detailed, comparative analysis of the accuracy of the SGN AR in SC-42 (Gojamanov, 2004). The analysis was made for differences of coordinates of points of triangulation 1 and 2 classes, calculated in both the SC. In the analysis the SC-95 was taken as a reference. SC-95 accuracy is characterized by the mean square error (MSE) transfer of coordinates on the edge of the network AGS of Commonwealth of Independent States $+1.02 \mathrm{~m}$ on the abscissa and $+1.10 \mathrm{~m}$ on the ordinate and the MSE error of the mutual position of related points $2-4 \mathrm{~cm}$. The territory of AR is a 27-trapezoid scale of $1: 200000$ and the studies conducted on these trapezoid. For each of the trapezoid calculated mean square amendments $\mathrm{dx}$ and dy to the coordinates of points 1 and 2 classes of triangulation in SC-42, average RMS offset $\mathrm{ds}$ and their corresponding 
average characterized by the RMS deviations Mdx, Mdy, Mds, composed of different maps that illustrate the changes in the values of these indicators on the territory of the Azerbaijan Republic (Fig. 2), and vector representation of displacements in the positions of points (Fig. 3). Data about the distribution of values $\Delta$ ds in SGN AR are in Table 1. By overall adjustment AGS USSR with the triangulation of 1 and 2 classes the points of SGN AR received the amendments in ranges: $0.95 \mathrm{~m} \leq \mathrm{dx} \leq 4.53 \mathrm{~m}, 2.71 \mathrm{~m} \leq$ $\mathrm{dy} \leq 6.55 \mathrm{~m}$, and the average values of the amendments are $d x=3.02 \mathrm{~m}$, $d y=4.15 \mathrm{~m}$. Values of linear displacements in the positions of the points in the SC-42 relatively to SC-95 are within $3.47 \mathrm{~m} \leq \mathrm{ds} \leq$ $6.78 \mathrm{~m}$, on the territory AR SC-42 is offset by an average value $d s^{\text {aver }}=5.29 \mathrm{~m}$ under the directional angle

$\alpha_{d s}=\operatorname{arctg}\left(\frac{d y^{\text {average }}}{d x^{\text {average }}}\right)=\operatorname{arctg}\left(\frac{4.15 m}{3.02 m}\right)=\operatorname{arctg}(1.347) \approx 54^{0}$.

In Figure 3 the displacement vectors are illustrated $d s$ in the positions of points in the SC-42 relatively to SC-95.

Trapezoids in the scale of 1:200 000 are 27.

Table 1 Distribution scatter shifts from the average across the AGS AR.

\begin{tabular}{lccccc}
\hline $\begin{array}{c}\text { The range in } \\
\mathrm{cm}\end{array}$ & $0-10$ & $10-20$ & $20-30$ & $30-40$ & $\begin{array}{c}1.0 \mathrm{~m} \\
\text { and } \\
\text { above }\end{array}$ \\
\hline The abscissas & 5 & 16 & 6 & - & - \\
Percentage & 18.5 & 59.2 & 22.3 & - & - \\
The ordinates & 4 & 19 & 3 & - & 1 \\
Percentage & 14.8 & 70.4 & 11.1 & - & 3.7 \\
Displacement & 3 & 8 & 12 & 3 & 1 \\
Percentage & 11.1 & 29.6 & 44.5 & 11.1 & 3.7 \\
\hline
\end{tabular}

A total quantity of the points of AGS AR - 829

\section{RESULTS OF REPEATED LEVELING ON THE ABSHERON PENINSULA}

The results of repeated leveling show that on the Absheron Peninsula there are significant movements of the Earth's surface. Analysis of instrumental data, morphostructural features and geodynamics of the Peninsula, produced by D.A. Lilienberg and I.N. Mesherski (Lilienberg, 1980), has allowed establishing that these movements have tectonic nature. At the same time lowering the areas connected with the oldest oil fields in Sabunchi, Surakhani, Ramana and Bibiheybat (for the period from 1912 until 1962, the general lowering of the Earth's surface Surakhani oil field has reached $2450 \mathrm{~mm}$ ), have been interpreted as the result of long-term oil and gas production, i.e. as a manifestation of anthropogenic factor on the background of purely tectonic movements. Azerbaijan with the adjacent water area of the Caspian Sea presents a lot of mud volcanoes. In the South-Eastern Caucasus, there are over 200, including about 30 active mud volcanoes.

\section{SEISMIC ACTIVITY ON THE TERRITORY OF AZERBAIJAN}

The territory of Azerbaijan for a long time differed for high seismic activity. So, Shamakhi district in Azerbaijan is most seismic active region of Caucasus. Earthquake foci in AR are scattered almost on the whole territory of the Republic. Over the past 25 years there have been earthquakes of great strength - 7-point on the Richter scale, such as, the Caspian (May 1980), Ismailly (November 1981), Caspian (March 1986), Lankaran (October 1987), Caspian (September 1989), on the border with Iran (February 1997), Lerik (July 1998), Baku (November 2000). Figure 4 presents a map of the epicenters of earthquakes on the territory of the AR from 1978 to 2001, compiled by the author according to the American Geophysical Society (Gojamanov, 2008). During this period, the number of earthquakes with the power of three or more points - 372, total the number of jerks - 1515 (average of the year), from them earthquakes force five and more points - 75 with the number of aftershocks 242 (average for the year). Shamakhi epicentral area against the background of other stands out with a 9-point isoseismal and 8: in Shamakhi city, Nakhichevan area, in the North of th Earth's e Absheron Peninsula, in Nagorno-Karabakh, Lenkoran area and in the border zone with Iran. Analysis of the distribution of earthquakes shows the high seismicity of the Caspian Sea, and the vast majority of epicenters of earthquakes are situated in the western band.

For Baku and some regions (Khizi, Shamakhi and other) Azerbaijan is characterized by recurrent landslide processes covering significant area (in Baku in 1998-th year landslides occurred with the area of about 100 ha and depth of about $30 \mathrm{~m}$ ), leading to the deformation of geodetic networks in these areas.

\section{GEODYNAMIC POLYGONS OF AZERBAIJAN}

In order to study the geodynamic regime in the most seismically active zones AR created six geodynamic polygons (GDP): Absheron special network -80, Shamakhi GDP, Caspian GDP, ShekiKurdamir GDP, Technogenic polygon Absheron, GDP Azerbaijan NPP. Their locations are shown schematically in Figure 5.

Absheron special network - 80. Regarding the level of works on the Absheron Peninsula, it can be noted that for the first time, given the paramount economic importance of the Peninsula, the Corps of Military Topographers in 1910-1912 performed on its territory I class leveling lines in the form of individual polygons. I class leveling line formed the basis for creation of one of the first in the world geodetic polygons for a comprehensive study of the recent vertical movements of the Earth's crust. Using the results of repeated leveling in different years oscillatory motion of the Earth's surface in Absheron are investigated. Many scientists' - A. Izotov's, D.A. Lilienberg's, I.N. Meshercki's and other's results of 


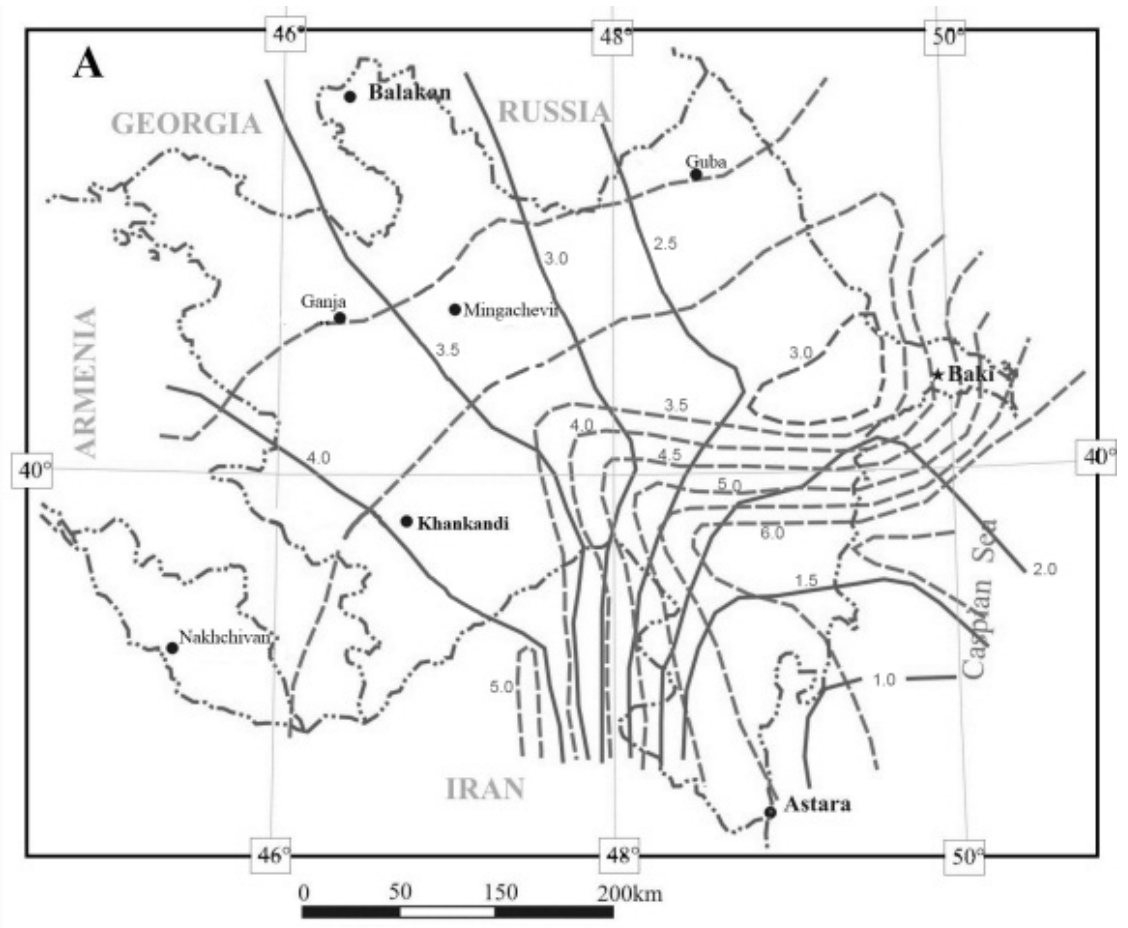
Isolines of the amendments on the $\mathrm{x}$-axis
Isolines of the amendments on the $\mathrm{y}$-axis
Section in meter

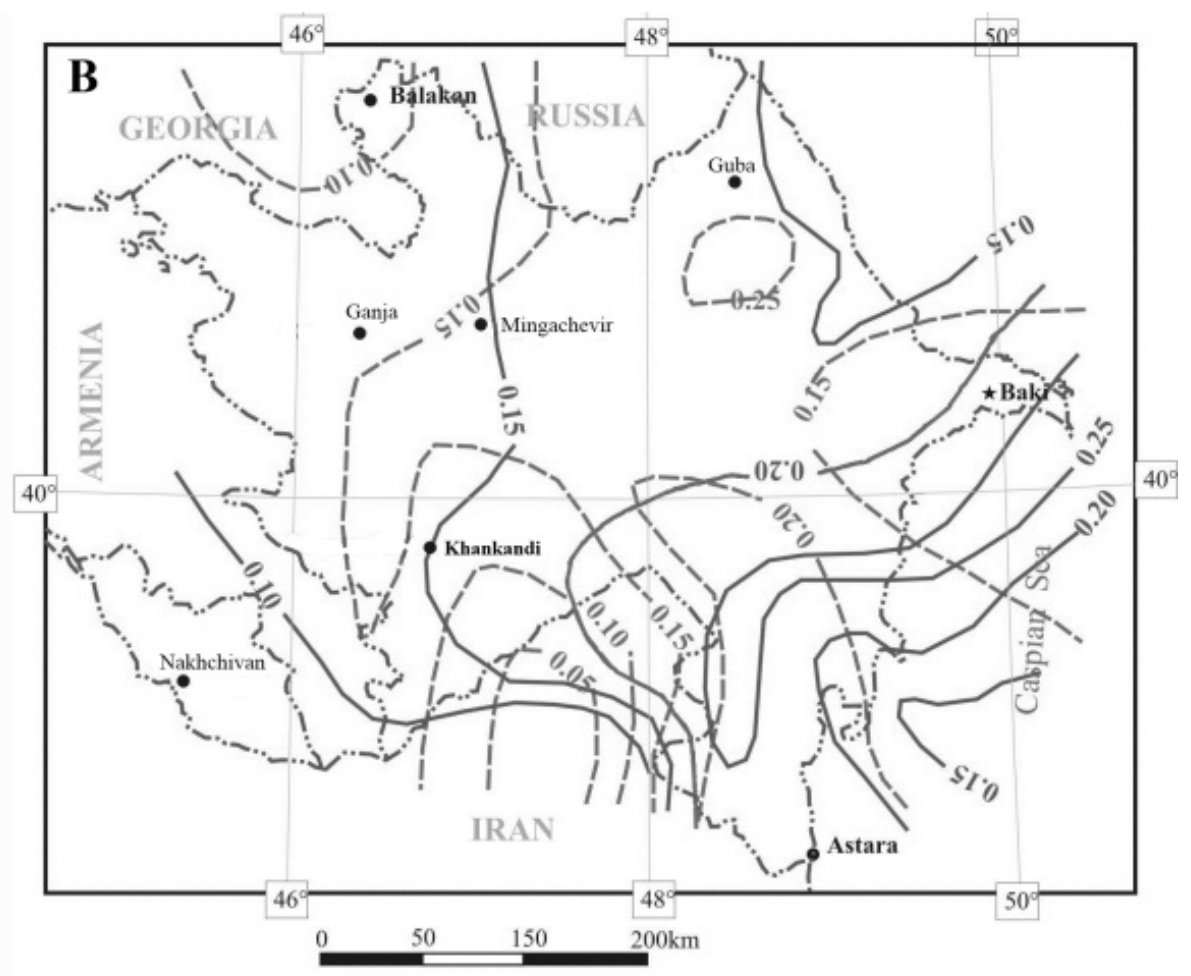

Isolines of the amendments on the $\mathrm{x}$-axis Isolines of the amendments on the $y$-axis Section in meter 

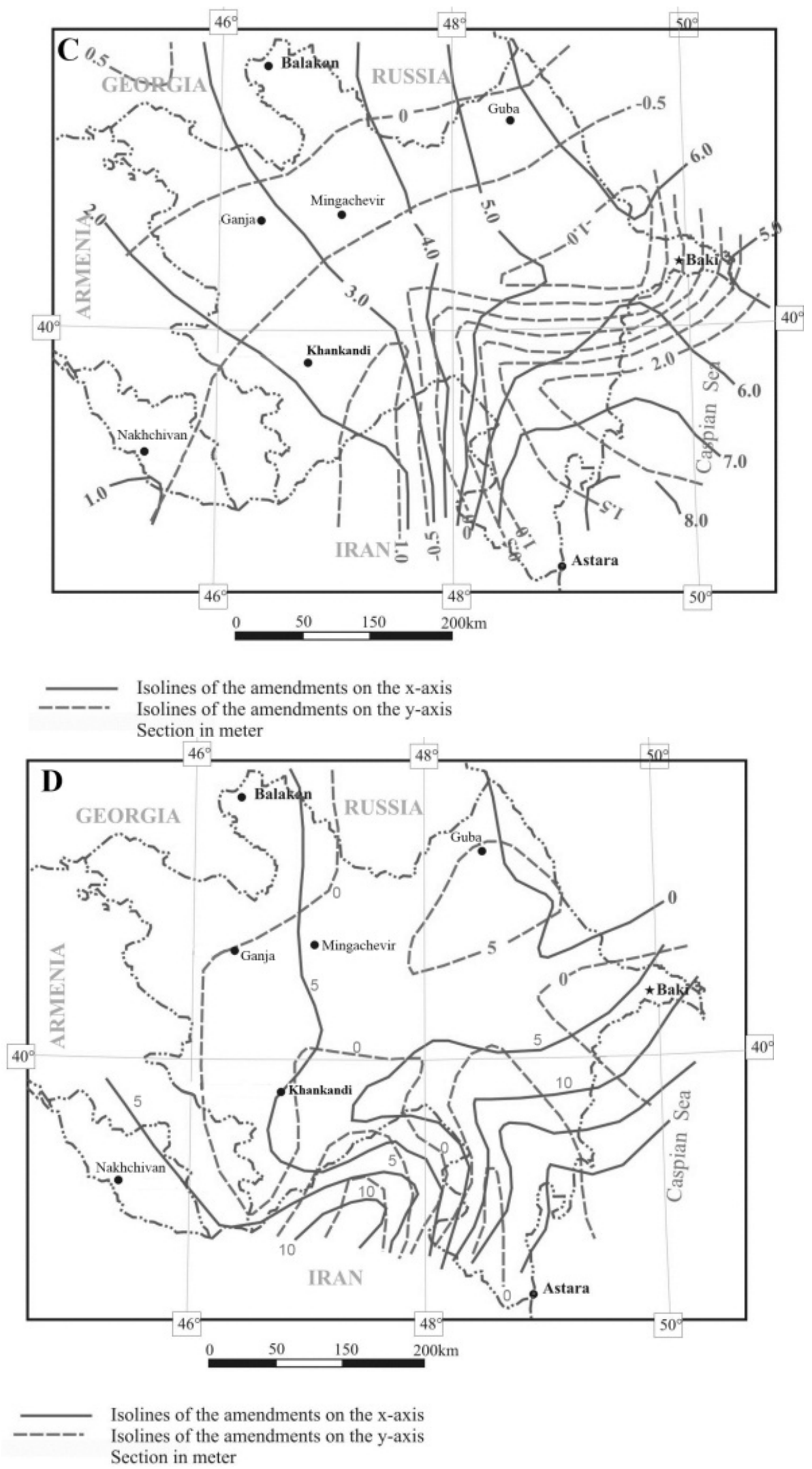

Fig. 2 Maps of amendments to the coordinates of points in the SC-42 and their variations on the territory of AR A) dx, dy; B) Mdx, Mdy; C) $\Delta d x, \Delta d y-($ in m); D) $\Delta \mathrm{Mdx} ; \Delta \mathrm{Mdy}$ - (in cm) 

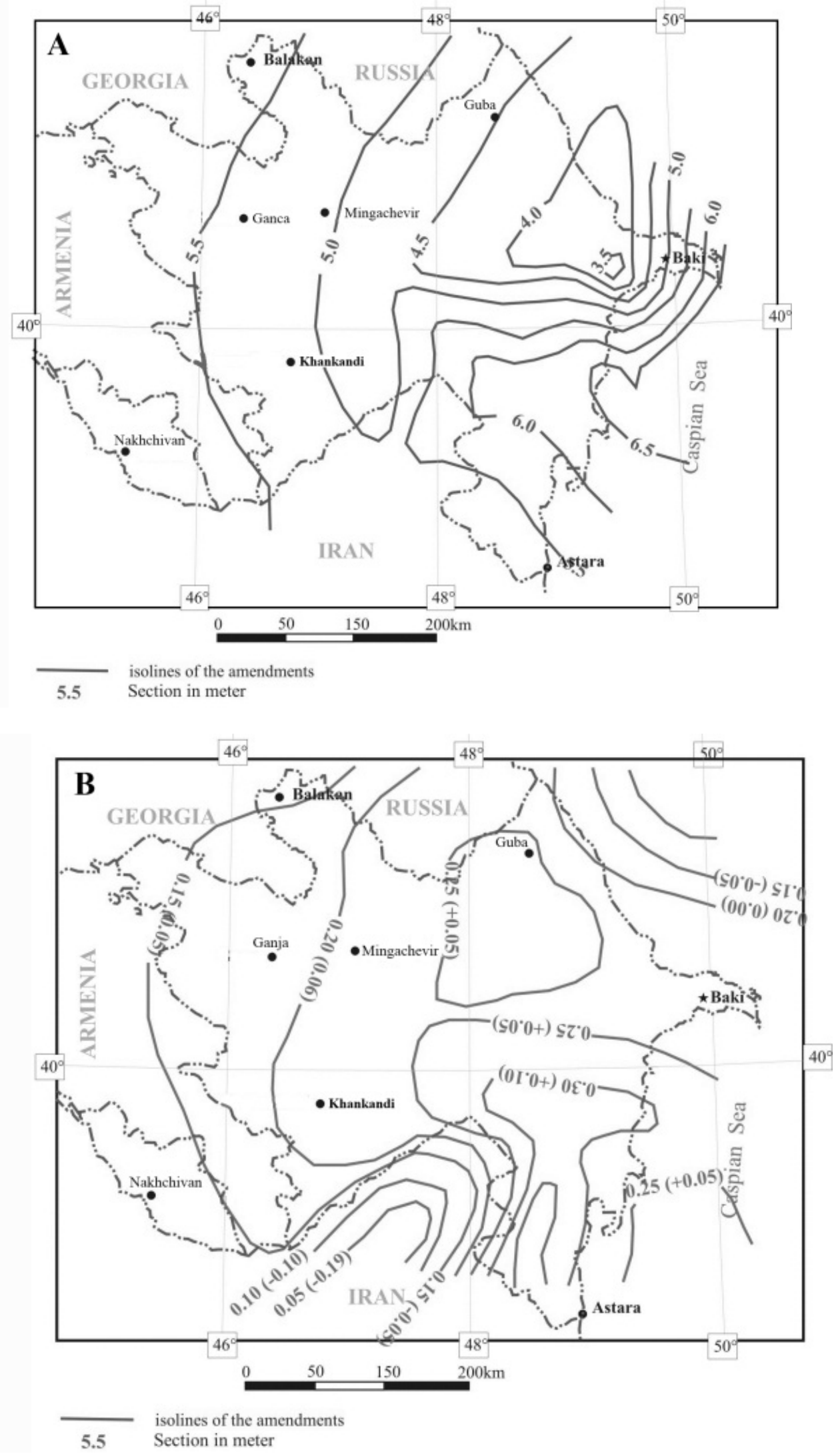

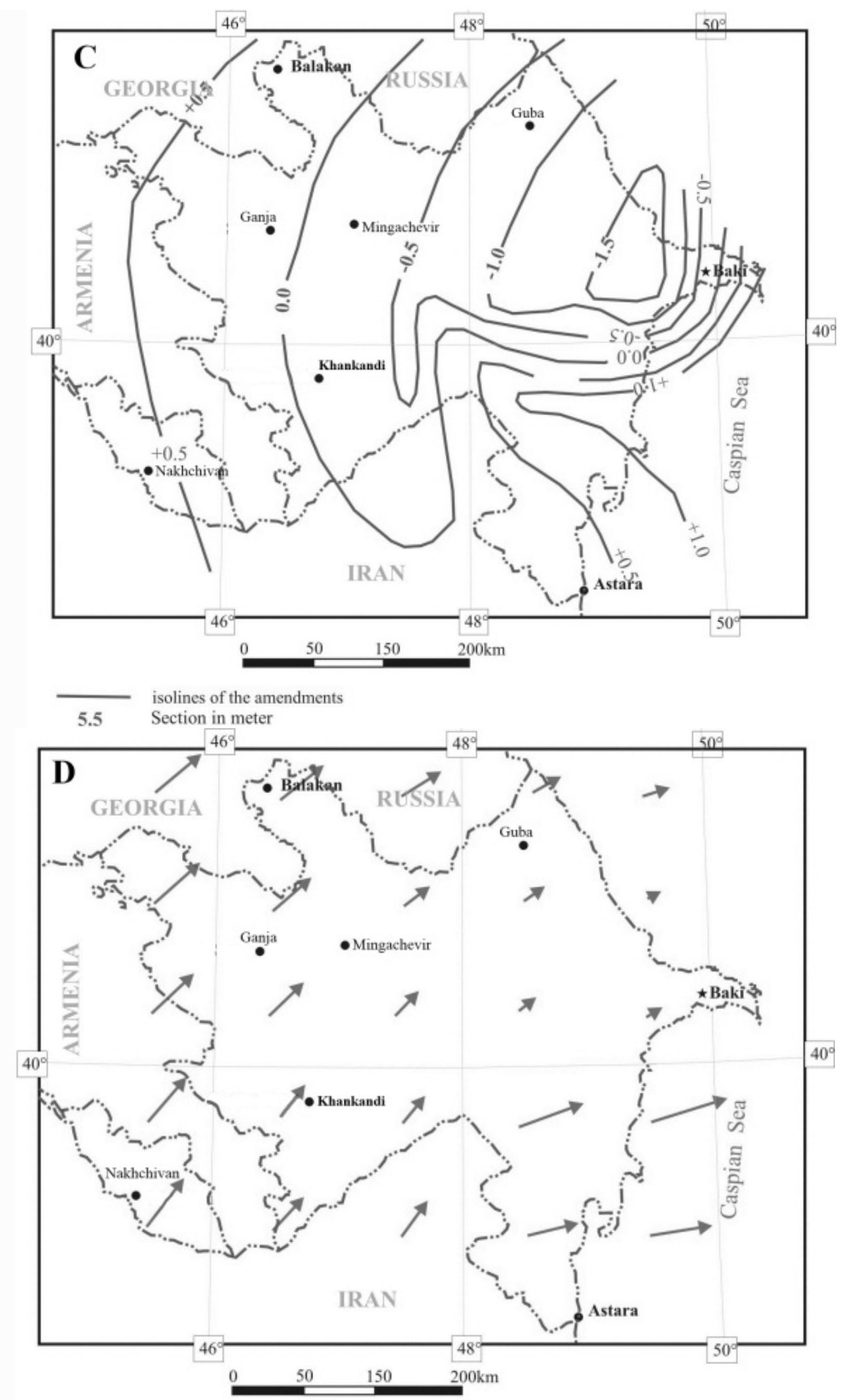

Fig. 3 Maps of linear displacements in the positions of points in the SK-42 and their distributions on the territory of AR.

A) ds; B)Mds ( $\Delta \mathrm{Mds})$; C) $\Delta \mathrm{ds}$; D) vector representation of ds 


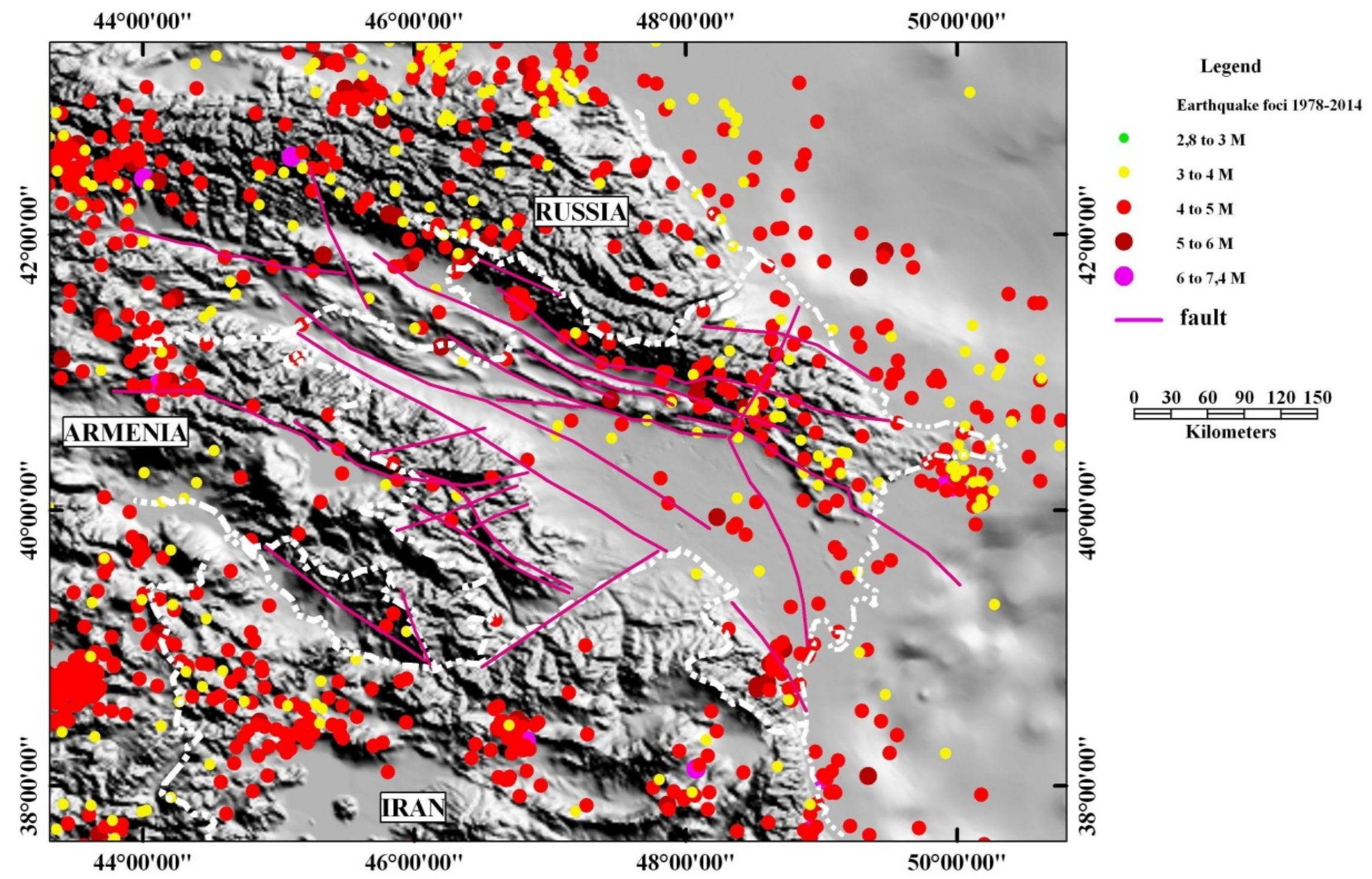

Fig. 4 Map of epicenters of earthquakes on the territory of Azerbaijan from 1978 till 2014. 


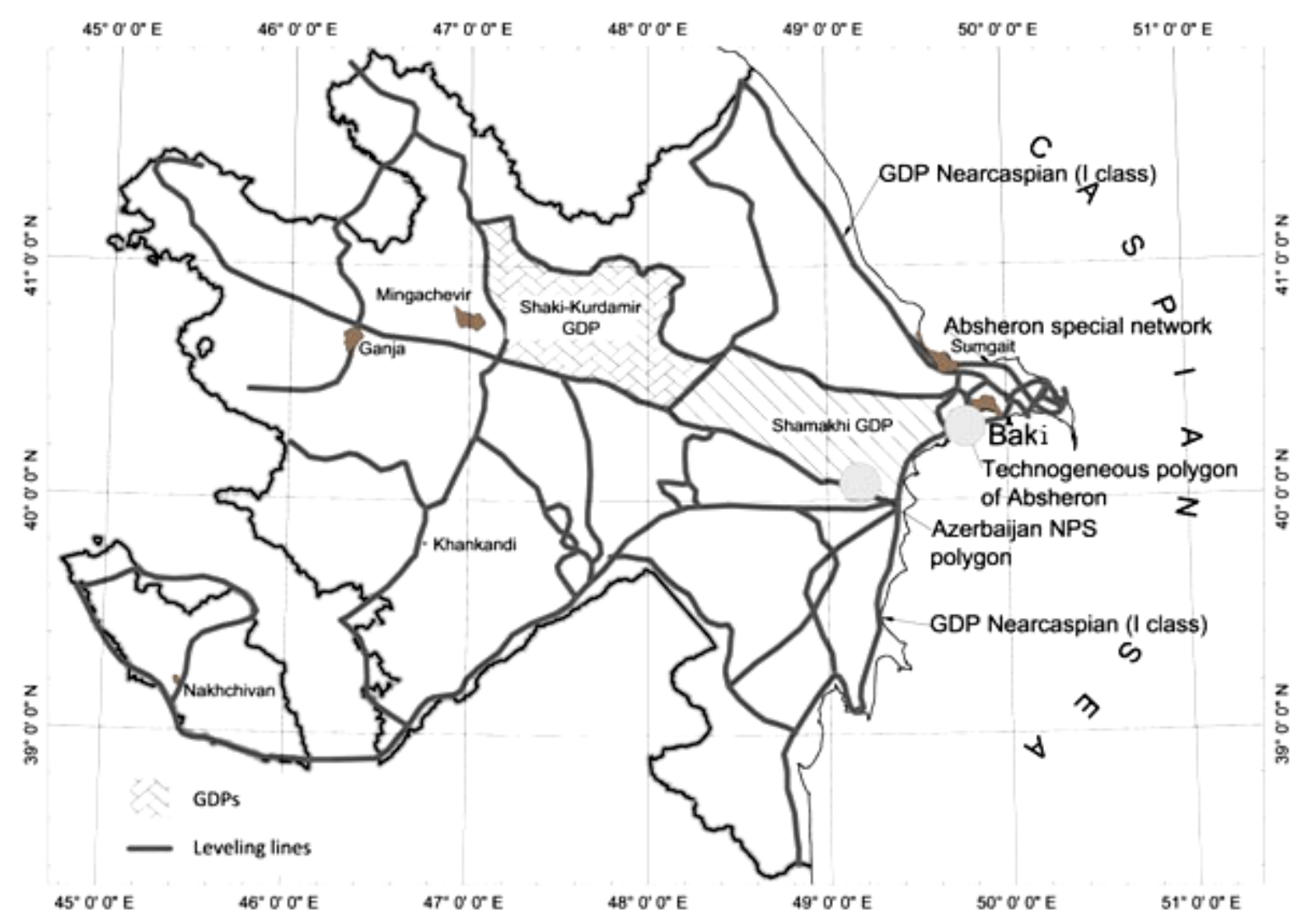

Fig. 5 Schema of location of geodynamic polygons.

re-leveling show that the surface of the Absheron Peninsula everywhere feels uneven deformation. In the Central part of the registered maximum lowering of the rate of $48 \mathrm{~mm} /$ year, and on the peripheral areas of the Peninsula it is sometimes replaced by show (Eminov and Subbotin, 1984).

Shamakhi geodynamic polygon was created in 1974 in the southeast part of the Great Caucasus. Over the past 150 years, there are more than 200 significant earthquakes, among which highlights the catastrophic earthquakes of 1859, 1869, 1872 and 1902, almost completely destroyed the city of Shamakhi and led to the death of tens of thousands of people. Geodetic basis of instrumental measurements of recent tectonic movements on the GDP are re-leveling and retriangulated. A polygon consists of a frame of the I class leveling line Baku-Kurdamir and three II class leveling lines: Kurdamir-Axsu, Hajievo-Maraza and Maraza-Duvanny, and linearly-angular network located on the territory of Shamakhi district to study horizontal movement on this territory. In coordination with the Institute of Geology of the National Academy of Sciences of Azerbaijan the Enterprise No16 (QUQK) from 1975 till 1985 regularly high-precision geodetic measurements on this GDP three cycles of linear and angular measurements of 1 class triangulation, I and II leveling classes carried out. The aim of these geodetic measurements on this GDP was also the targets detection of possible earthquake precursors. The results of the comparison of measurements from different cycles show that Shamakhi GDP there is intense movement of the Earth's crust, as in a high-rise, and the plan arrangements. During the last decades at the polygon repeated geodetic measurements were not made.

Caspian geodynamic polygon is created in 1981 along the western coast of the Caspian Sea from Makhachkala to Astara on the territories of the Dagestan Republic and the Azerbaijan Republic. In the course of the I class leveling line gravimetric points from the "Gravimetric points of geopolygon" were included. The leveling lines constructed in 1950, 1971, partly in 1912, 1936, 1940-1944 and 1976 were also included in the polygon. Recent geodetic measurements on this test network were performed in 1982-1986. I vlase leveling lines amounted $1253.3 \mathrm{~km}$, II class $56.8 \mathrm{~km}$. On the general background there is a sharp rotation direction of movement of the Earth's crust along the lines of Makhachkala-Astara.

Geodynamic polygon Sheki-Kurdamir was created in 1982-1984, in the southeastern Caucasus (areas: Agdash, Aksu, Gabala, Goychay, Yevlakh, Ismayilli, Oghuz, Kurdamir, Ujar, Sheki) to detect preceding the earthquake deformation of the Earth's surface. A polygon consists of linearly-angular first 
class network, of level lines of I and II classes. In 1985 two cycles ( 7 and 8 cycles) were performed. The results of measurements suggest that in the area of the polygon the horizontal and vertical movements of the Earth's crust occur was oscillatory character.

Technogenic polygon Absheron was located in the areas of extraction of oil and gas extraction in Lokbatan, Puta, Kushxana of Absheron Peninsula. In 1986 a cycle of measurements I and II classes of leveling was made: $130.6 \mathrm{~km}$ and $49.7 \mathrm{~km}$ respectively on newly laid benchmarks and $51.3 \mathrm{~km}$ re-leveling of the earlier built ones. In 1987 a cycle of II measurements of leveling classes I and II was implemented: total length - $103.2 \mathrm{~km}$. The main scientific task in the organization of this site was to examine the influence of oil and gas extraction on the movement of the Earth's surface and the establishment of parities of the latter with the slow vertical movements.

Geodynamic polygon Azerbaijan nuclear power plant (NPP) is located north of the station Navai in Pirsaat valley. In 1985, 11 deep and 143 ground benchmarks were laid down. I class leveling line was projected on the existing I class leveling line of AlatKhashuri. In 1985-1987 there were done three cycles (interval between cycles was 1 year) of I class leveling line with the length of $69.5 \mathrm{~km}$, II class $-67.5 \mathrm{~km}$. The purpose of creation of this network was to study the seismicity of the area, where the Azerbaijan NPP will be projected. Currently repeated measurements at the polygon are terminated in connection with the suspension of nuclear power plant construction.

\section{CONCLUSION}

From the above mentioned it follows that in Azerbaijan there are complex geodynamic processes. Under the influence, in particular, these processes deformed the State Geodetic Network of AR.

Here the values Mdx, Mdy in the network can be interpreted as MSE of transfer of coordinates $\mathrm{X}$ and $\mathrm{Y}$, and the Mds as an error of positioning of points within, in our case, trapeze 1:200000. Fluctuations of values Mdx, Mdy and Mds in trapezes have unacceptably wide ranges what is the direct evidence of heterogeneity of SGN AR on accuracy.

On the other side uneven and significant fluctuations of the values of $\mathrm{dx}$, dy and $\mathrm{ds}$ in trapezes can be interpreted as a manifestation of weak internal network rigidity, bad coordination of relations between its separate units (trapeziums), deformations of the SGN AR in SC-42. Therefore it is necessary in the coming years to continue the reconstruction and modernization of SGN AR on the basis of the satellite technologies.

Since the last leveling activities on the territory of the Azerbaijan Republic in last 25 years, it can be assumed that a significant number points of frames of height control (FHC) had been lost (destroyed) as a result of various anthropogenic processes in the cities, villages, repair and construction works on transport communications along which as usually laid leveling line. According to the instructions, line leveling class I and part-lines II class at least once every 25 years, and in mountainous, seismically active areas (that is to say, Azerbaijan), in every 15 years must be resmoothed over with the purpose of their modernization, as well as to obtain the quantitative characteristics of the recent vertical movements of the Earth's surface. However, since 1984 in FHC of Azerbaijan and in some of its lines even earlier period, there were not any practically produced works on updating and repetition of leveling lines of I and II classes. It is, therefore, within the next years to perform the works on modernization and development FHC of the Azerbaijan Republic.

For more accurate and detailed study of the geodynamic processes the observations on geodynamic polygons should be resumed, with the need to reduce the size of polygons.

\section{REFERENCES}

Bazlov, Y.Z., Galazin, V.F., Kaplan, B.L., Maximov, V.I. and Chugunov, I.P.: 1996, Analysis of results of the joint equalization astronomical and geodetic, Doppler and space geodetic networks. Geodesy and Cartography, No. 7, Moscow, 26-37.

Efimov, G.N.: 1995, Adjustment results astronomicalgeodetic network. Geodesy and Cartography, No. 8, Moscow, 17-22.

Eminov, R.A. and Subbotin I.E.: 1984, Analysis of vertical displacements of the Earth's surface in the oil fields of Absheron Peninsula. Geodesy and Cartography, No. 2, Moscow, 43-45.

Gojamanov, M.H.: 1998, Stages of construction of the astronomical-geodetic network on the territory of AR. Scientific conference dedicated to the 50th anniversary of the Geographical Society of the Republic of Azerbaijan, BSU, Baku, 55-56.

Gojamanov, M.H.: 2004, Analysis of the existing condition of the State Geodetic Network of the Azerbaijan Republic. Geodesy and Aerial Photography, No. 1, Moscow, 13-25.

Gojamanov, M.H.: 2008, Reconstruction and development of geodetic networks with the use of satellite technology, Moscow-Baku, $256 \mathrm{pp}$.

Kashin, L.A.: 1999, Build classical astronomical and geodetic network in Russia and the USSR (18161991). Scientific-technical and historical review. Kartgeotcentr-geodezizdat, Moscow, 192 pp.

Khain, V.E. and Alizade, A.A.: 2005, Geology of the Azerbaijan, IV, Baku, Nafta-Press, 506 pp.

Lilienberg, D.A.: 1980, Experience of complex mapping of modern geodynamics (for example, AZ. SSR), Crustal movements: Theory, methods, problems, Moscow, $65-76$.

Makarenko, N.L.: 1996, About switching to autonomous satellite systems methods of definition of coordinates. Geodesy and Cartography, No. 5, Moscow, 4-7.

Museibov, M.A.: 1998, Physical geography of Azerbaijan (in Azerbaijani), Maarif, Baku, 400 pp.

Yashenko, W.R.: 1989, Geodetic researches of the vertical movements of the Earth crust, Moscow, Nedra, 192 pp. 